\title{
NATIVE CONIFERS
}

\section{Of Saskatchewan}

\author{
by VERNON L. HARMS*
}

The conifers are important trees and shrubs in the Saskatchewan flora, including ecological dominants of the Cypress Hills and northern coniferous forests. The conifers are mostly evergreens and belong to the general group of plants known as Gymnosperms which have naked seeds usually borne in cones, in contrast to the Angiosperms (or flowering plants) which have their seeds enclosed in ovaries and are borne in flowers. The conifers are often referred to by the group name "Evergreens" although a few species, such as our Tamarack and the Bald Cypress of southern United States, have deciduous leaves while, on the other hand, many flowering plants, such as most heath shrubs, have evergreen leaves.

This paper is intended as a simple guide to the identification of the native conifers of Saskatchewan and their description. There are eight native species in the province, including six trees - Tamarack, Jack Pine, Lodgepole Pine, Black Spruce, White Spruce and Balsam Fir - and two shrubs - Creeping Juniper and Ground Juniper. Of course, any of the tree species may be shrub-sized in young stages. The illustrated identification key of Figure 1 should allow the reader to correctly determine the species of any unknown native conifer. It should be pointed out that various non-native species of conifers are often distributed by nurseries and planted in parks, yards and farmsteads, and the key does not cover these. Some of the more common introduced conifers planted in the province are Colorado Blue Spruce, Scotch Pine, Mugho Pine and various varieties of Juniper and Arbor Vitae (Cedar). Leafy twigs and

\footnotetext{
* Fraser Herbarium,

Dept. of Plant Ecology,

University of Saskatchewan,

Saskatoon, Saskatchewan.
}

cones of the eight native conifel species are illustrated in the drawing: of Figure 2.

1. Tamarack (Larch), Larix laricinc (Du Roi) K. Koch. Tamarack is : tree of wet boggy habitat: throughout the northerr coniferous forest in Saskatchewan The trees have straight tapering trunks and a narrow open crowr allowing most branches to be visible. The upper branches are distinctly upcurved. The trees may reach a height of 70 feet with a diameter of 20 inches, but are usually 30-60 feet high and only $5-10$ inches in diameter. The bark of younger trees is thin, light brown and smooth; the bark of older trees is orange-red, deeply furrowed and loosely scaly. The needles are $1 / 2$ to 1 inch long and are mostly borne in crowded clusters of 12-20 from small knobby spurs on the twigs Young shoots and leaders show: spiral arrangement of the needles The needles are a yellow-green colour in summer, but turn a light yellow in autumn and then drop off. It is the only deciduous. leaved conifer species in Saskat. chewan; all other conifers in the province are evergreen. The cones are round and small, about $1 / 2$ inch long.

2. Jack Pine, Pinus banksiana Lamb Jack Pine is a common tree in the northern forest of Saskatchewan. often forming extensive stands on drier, well-drained sites. The trees are tall, 50 to 75 feet high. and $8-15$ inches in diameter with relatively narrow crowns. The bark is mottled, dark brownishgray, with small loose scales. The evergreen needles are $1-21 / 2$ inches long, two to a bundle, and 


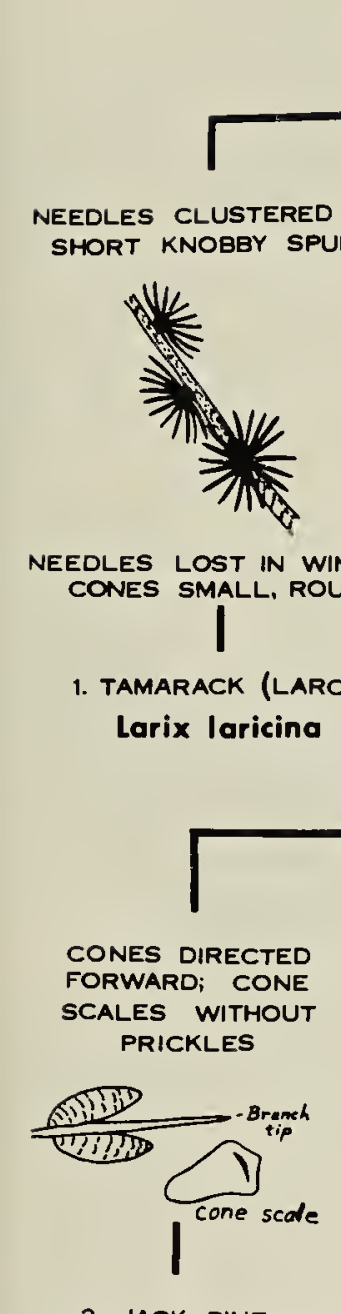

2. JACK PINE

Pinus banksiana

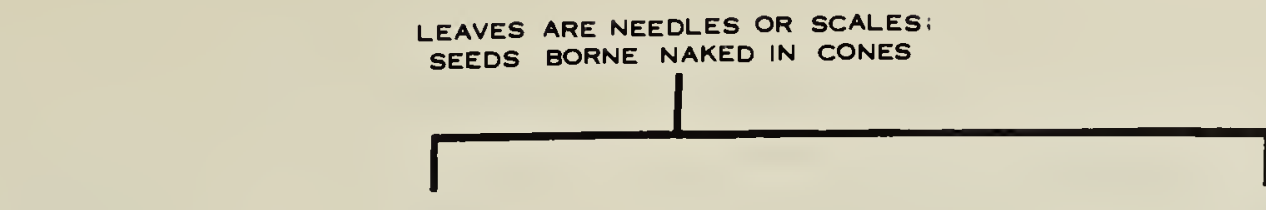

TAVES ARE NEEDLES OR SCALES SEEDS BORNE NAKED IN CONES

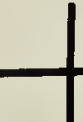

NEEDLES IN BUNDLES of 2

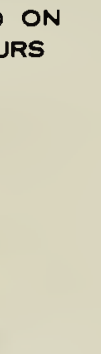

WUNE

NER:


NEEDLES SPIRALLY ARRANGED

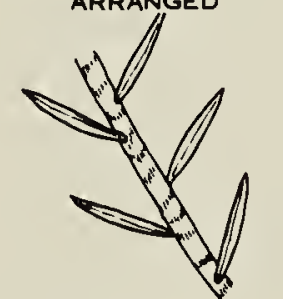
OPPOSITE OR WHORLED

SHRUBS

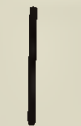
CONES BERRY-LIKE



MOST LEAVES SCALELIKE, OPPOSITE, ABOUT 1/ 16 INCH LONG

AVES AWL-SHAPED, IN WHORLS OF 3 .

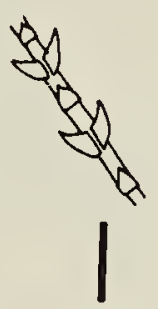
$1 / 5-1 / 2$ INCH LONG

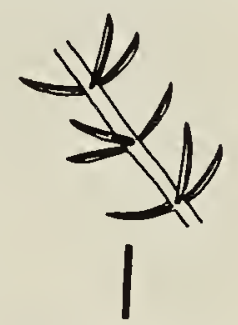
Juniperus communis

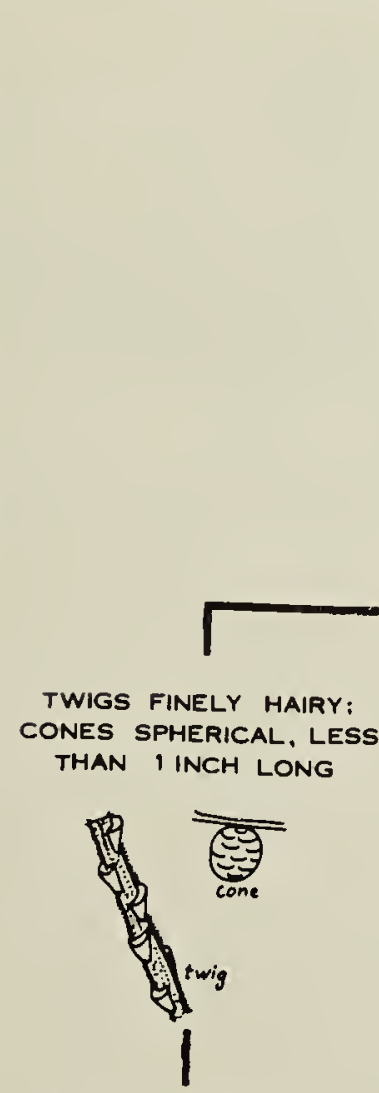

4 BLACK SPRUCE Picea mariano
7. CREEPING JUNIPER Juniperus horizontalis

3. LODGEPOLE PINE Pinus contorta OUTWARD OR BACKWARD; CONE
SCALES WITH PRICKLE
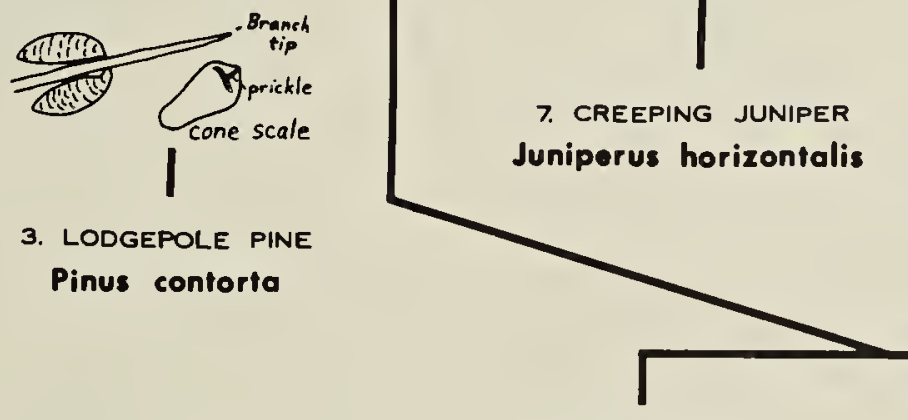

TWIGS ROUGHENED BY LEAF BASES: NEEDLES 4-SIDED, POINTED

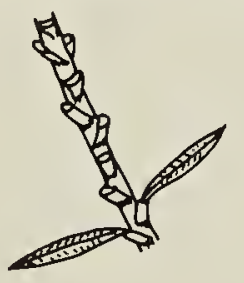
CONES ELONGATED, OVER I INCH LONG

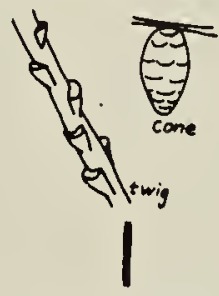

5. WHITE SPRUCE

Picea glauca
Fig. 
light green in colour. The cones are hard, oval, directed strongly forward, and often remain on the trees for several years. The cone scales are naked, lacking the prominent prickle of the closely related and similar Lodgepole Pine.

3. Lodgepole Pine, Pinus contorta Dougl. var. latifolia Engelm. Trees of Lodgepole Pine usually grow in dense stands and then are tall and slender with narrow crowns. The trees are 40-75 feet high and 8-15 inches in diameter. The branches generally curve upward. The bark is mottled, dark gray or brownish, with a light covering of small loose scales. The evergreen needles are 1-2 1/2 inches long, two to a bundle, and often have a yellowish-green tinge. The cones are hard, oval, directed outward or backward, and often hang unopened on the trees for several years. The cone scales bear a small curved prickle on their back near the tip. Lodgepole Pine is limited to the Cypress Hills in Saskatchewan.

4. Black Spruce, Picea mariana (Mill.) B.S.P. Black Spruce is a tree characteristically found in bogs, muskegs, and cold wet flats throughout the northern forest area in Saskatchewan. It is also common on uplands northward on the Precambrian Shield. The trees may reach 70 feet in height and 10 inches in diameter but most are shorter, only 10-30 feet high and 3-6 inches in diameter. Most branches are short, sparse, and horizontal to drooping at the ends. The bark is thin with gray to blackish scales. The twigs are slender, often blackish, and are covered with a fuzz of short reddish brown hairs. The needles are stiff, 4-angled, short-stalked, ashy blue-green and about 1/4-1/2 inch long. The seed cones are almost spherical, gray-brown to purplish, small, 1/2-1 inch, curved downward and usually in clusters that often remain on the tree for several years.
5. White Spruce, Picea glauca (Moench) Voss. White Spruce is a common tree of the Cypress Hills and northern coniferous forest in Saskatchewan. When growing in thick stands, the trees are narrowly triangular with a straight trunk. The topmost branches curve upward, but the lower branches droop downward. The trees may reach 100 to 130 feet in height in favorable sites, but more commonly are 40-70 feet high and 6-20 inches in diameter. The bark is covered with thin, grayish to brownish scales, and is reddishbrown between and beneath the scales. The twigs are roughened by prominent leaf bases and are hairless. The leaves are 4-sided, sharp-pointed, short-stalked and 1/2-1 inch long. The seed cones are brown, symmetrical, oblong, 1-2 inches long and hang downward.

6. Balsam Fir, Abies Balsamea (L.) Mill. Trees of Balsam Fir occur in moist woods intermixed with white spruce, poplar, aspen, and other species, throughout the northern coniferous forest in Saskatchewan. Despite its prominence in the northern coniferous forest of eastern Canada, nowhere in this province is it an abundant species. The trees have straight trunks and narrow, symmetrical crowns with the branches appearing in distinct whorls. The trees may reach up to 80 feet in height and 20 inches in diameter, but most are considerably smaller. The bark of young trees is gray, thin and smooth with conspicuous resin blisters; that of older trees is reddish and scaly. The twigs are relatively smooth with round leaf scars. The needles are flat, blunt, 1/2-1 inch long and are widespreading, forming flattened sprays on lower branches. The needles of spruces and firs can be distinguished quite easily by the fact that a fir needle will not roll between the fingers whereas a spruce needle will. The seed cones 


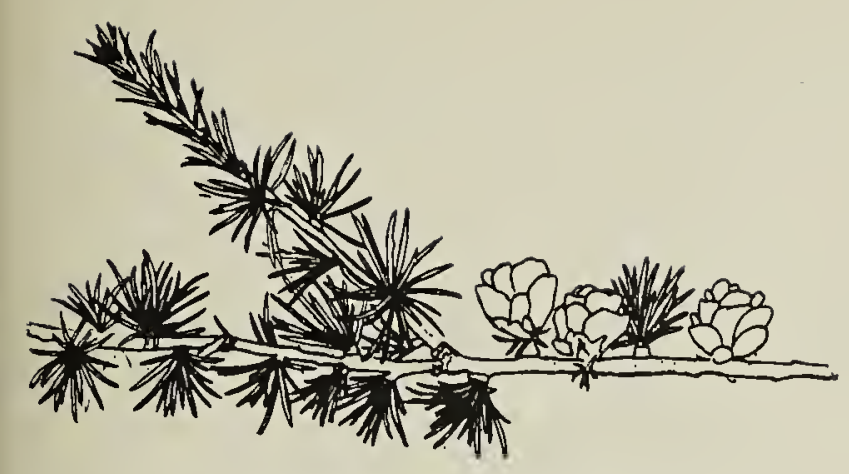

1. TAMARACK (LARCH)

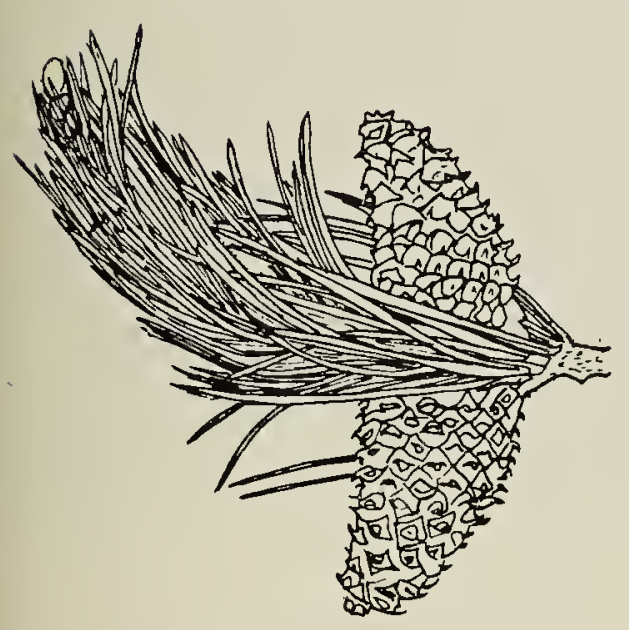

3. LODGEPOLE PINE

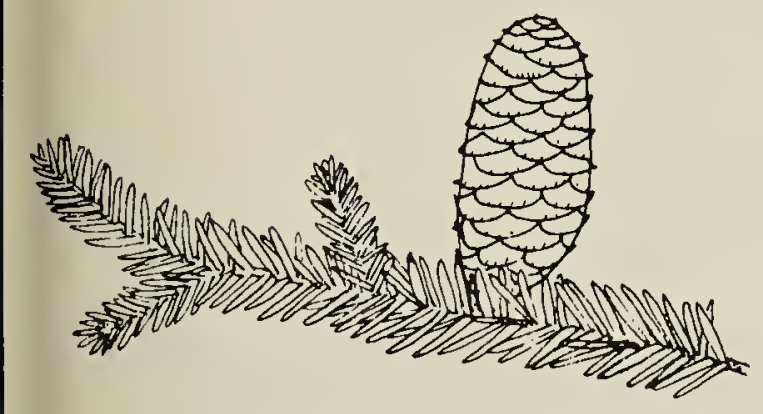

6. BALSAM FIR

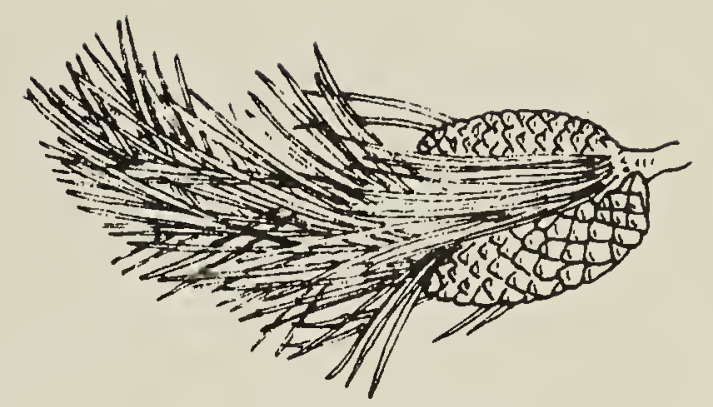

2. JACK PINE

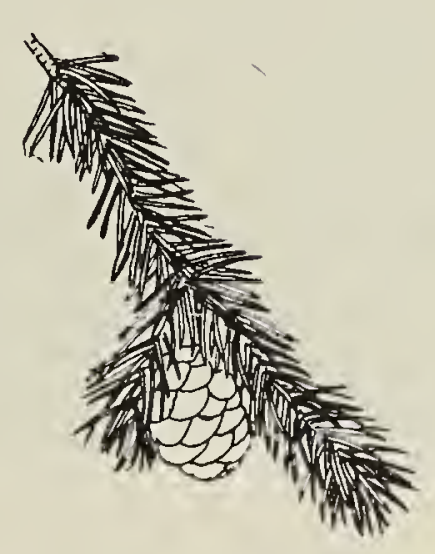

4. BLACK SPRUCE

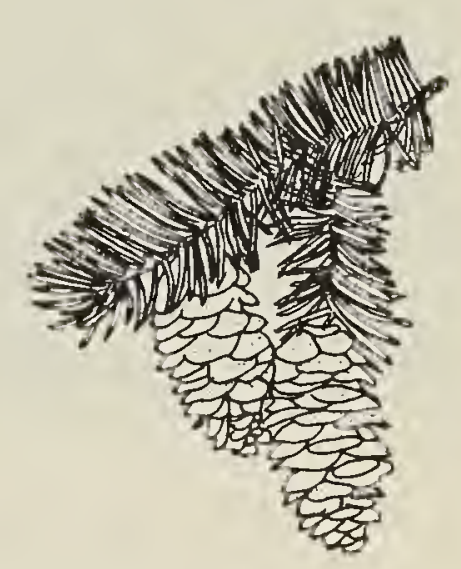

5. WHITE SPRUCE


8. GROUND JUNIPER

Fig. 2. Leafy twigs and cones of the eight native conifer species in Saskatchewan. 
of Balsam Fir are 2-4 inches long purplish, and erect.

7. Creeping Juniper (Creeping Savin), Juniperus horizontalis Moench. Creeping Juniper is a prostrate or trailing evergreen shrub with long horizontal, often rooting, stems giving rise to short erect twigs, 2-6 inches high. The leaves are opposite, mostly scalelike, 1/16 inch long, blunt and bluish green. On young plants and leaders, however, the leaves may be awl-shaped, sharp-pointed and about $1 / 4$ inch long. The seed cones are blue with a whitish bloom, round, berry-like and about $1 / 4$ inch in diameter. Creeping Juniper is found on dry river banks and sandy knolls, particularly in the southern third of the province, although it is occasional in the northern coniferous forest as well.

8. Ground Juniper (Common Juniper, Dwarf Juniper), Juniperus communis L. Ground Juniper is a low, spreading evergreen shrub reaching only about 2 feet in height and often forming large clumps. The bark is thin, dark reddish-brown to gray, rough and scaly. The leaves are awl-shaped, 1/4-1/2 inch long, less than $1 / 16$ inch wide, stiff, sharply pointed, whitish and grooved below, shiny yellow-green above and whorled in threes. The seed cones are dark blue covered with a whitish bloom, round, berrylike, hard and about $1 / 4$ inch in diameter. Ground Juniper is found throughout Saskatchewan on riverbanks and exposed hills both in the prairies and in the northern woods, although it is somewhat rare in the latter area.

\title{
NODDING TRILLIUMS
}

\section{In Eastern Saskatchewan}

\author{
by BERNARD De VRIES*
}

En route to the Saskatchewan Natural History Society field-meeting at Hudson Bay, Saskatchewan, my wife and I tried to relocate the known locations of Nodding Trillium (Trillium cernuum L., fig. 1) in eastern Saskatchewan. Previous field trips in 1971 and 1972 were unsuccessful; however, Trillium cernuum L. variety cernuum and variety macranthum Eames and Wieg. were discovered at four separate and additional locations in eastern Saskatchewan between June 14 and $17,1973$.
Rather small, but well established populations of Nodding Trillium occur in aspen (Populus tremuloides) woods, mainly in association with Speckled Alder (Alnus incana), and on one occasion in a damp SpeckledAlder - Ostrich Fern (Matteucia struthiopteris) woods.

The Saskatchewan localities are listed below with the number of each voucher specimen in the Fort Qu'Appelle (Sask.) Herbarium:

* Fort Qu'Appelle Herbarium,

Fort Qu'Appelle, Saskatchewan. 